\title{
Chrysin induces cell apoptosis via activation of the p53/Bcl-2/caspase-9 pathway in hepatocellular carcinoma cells
}

\author{
QINGYU ZHANG ${ }^{*}$, SHENG MA* ${ }^{*}$ BIN LIU, JIE LIU, RUNZHI ZHU and MINGYI LI \\ Laboratory of Hepatobiliary Surgery, Affiliated Hospital of Guangdong Medical University, \\ Zhanjiang, Guangdong 524001, P.R. China
}

Received April 1,2015; Accepted March 18, 2016

DOI: $10.3892 /$ etm.2016.3282

\begin{abstract}
Chrysin is a major active ingredient of flavonoids, known to exhibit protective effects against various types of cancer. However, the anticancer role of chrysin against hepatocellular carcinoma (HCC) and the underlying molecular mechanisms remain unclear. In order to evaluate the effects of chrysin on cell viability and apoptosis in human HCC, HepG2 and QGY7701 cells were used in the present study. Cell viability was monitored using an MTT assay. In addition, an Annexin V-fluorescein isothiocyanate/propidium iodide kit was used for the labeling of the apoptotic cells, which were then measured using flow cytometry. Western blotting was used to examine the protein expression of p53, B-cell lymphoma-2 (Bcl-2), Bcl-2-associated X (Bax), Bcl-2-associated death promoter (Bad), Bcl-2 homologous antagonist/killer (Bak), caspases-3 and -9 , and cleaved-caspases-3 and -9 . The results of the present study revealed that chrysin suppressed the cell viability of HepG2 and QGY7701 cells in a concentration-dependent manner. In addition, chrysin induced significant apoptosis in HepG2 and QGY7701 cells. Furthermore, it was demonstrated that chrysin treatment increased the expression of proapoptotic proteins, including p53, Bax, Bad and Bak, while it decreased the protein level of antiapoptotic protein Bcl-2. It was also demonstrated that chrysin induced apoptosis in the HCC cells by regulating the $\mathrm{p} 53 / \mathrm{Bcl}-2 /$ caspase- 9 signaling pathway. In conclusion, the results of the present study suggested that chrysin may be a potential candidate agent for the induction of cell apoptosis in human HCC.
\end{abstract}

Correspondence to: Professor Mingyi Li or Dr Runzhi Zhu, Laboratory of Hepatobiliary Surgery, Affiliated Hospital of Guangdong Medical University, 57 Renmingnan Road, Zhanjiang, Guangdong 524001, P.R. China

E-mail: limingyi63@163.com

E-mail: hepatolab@163.com

*Contributed equally

Key words: p53/B-cell lymphoma-2/caspase-9 pathway, chrysin, hepatocellular carcinoma

\section{Introduction}

Hepatocellular carcinoma (HCC) has become a global health problem, as it is the third most common cause of cancer-associated mortalities worldwide, with $>800,000$ mortalities per year $(1,2)$; however, systemic treatment options for HCC are limited. Surgery remains the most efficacious and mainstream solution for the eradication of cancer nodules; however, relapse and distant organ invasion are common following tumor dissection (3). Anti-tumor agents have demonstrated strong cytotoxicity against cancer cells and oral administration of chemotherapeutics is recommended for the clearance of tumor cells that survive tumor dissection (4). Therefore, choosing appropriate anti-tumor agents and planning their administration is an indispensable part of systemic treatment HCC.

Natural products have been widely used in the development of various anticancer drugs. Paclitaxel, which is extracted from bark of the Pacific yew (Taxus brevifolia), has been successfully used to treat breast, lung and ovarian cancer (5). Chrysin, a natural flavonoid that is commonly found in honey and bee propolis (Fig. 1), is known for its various biological activities $(6,7)$. Previous studies have suggested that chrysin possesses antioxidant (8), antihypertensive (9), antidiabetogenic (10) and anxiolytic properties (11). In addition, chrysin exerts a strong anticancer effect in multiple types of human cancer, since it induces cell cycle arrest and cell apoptosis (12); however, whether chrysin may be used as a novel antitumor drug against $\mathrm{HCC}$ has not been extensively investigated.

Therefore, the aim of the present study was to examine the anticancer effect of chrysin on HCC cells, and determine the underlying mechanism of chrysin-induced apoptosis in HepG2 and QGY7701 human HCC cells.

\section{Materials and methods}

Cell culture. HepG2 and QGY7701 cells were provided by The Cell Bank of Type Culture Collection of Chinese Academy of Sciences (Shanghai, China). Cells were cultured in RPMI 1640 supplemented with $10 \%$ heat-inactivated fetal bovine serum plus $100 \mathrm{U} / \mathrm{ml}$ penicillin and $100 \mu \mathrm{g} / \mathrm{ml}$ streptomycin (all Thermo Fisher Scientific, Inc., Waltham, MA, USA) at $37^{\circ} \mathrm{C}$, in a humidified atmosphere of $5 \% \mathrm{CO}_{2}$. Chrysin was diluted to various concentrations with cell culture media. After the 
cells had reached $60 \%$ confluence, various concentrations of chrysin were added $(0,10,15,20,25,30,40$ and $50 \mu \mathrm{g} / \mathrm{ml})$.

MTT assay. Cells were seeded in 96-well plates at a density of 5,000-10,000 cells/well. Different concentrations of chrysin $(0,10,15,20,25,30,40$ and $50 \mu \mathrm{g} / \mathrm{ml} ; 5$ replicates per concentration group) were added to the cell cultures for $24 \mathrm{~h}$, followed by $20 \mu \mathrm{l}$ MTT solution $(5 \mathrm{mg} / \mathrm{ml}$; Beyotime Institute of Biotechnology, Shanghai, China). After incubation for $4 \mathrm{~h}$ at $37^{\circ} \mathrm{C}$ in an atmosphere of $5 \% \mathrm{CO}_{2}$, supernatants were removed and $150 \mu \mathrm{l}$ dimethyl sulfoxide (Beyotime Institute of Biotechnology) was added. The plates were then placed on an orbital shaker for $10 \mathrm{~min}$. Subsequently, the absorbance at $490 \mathrm{~nm}$ was measured using a spectrophotometer (EnSpire 2300 Multilabel reader; PerkinElmer Inc., Waltham, MA, USA). The inhibitory rate was calculated according to the following formula: (A490 control $\left.^{-\mathrm{A}} 490_{\text {treated }}\right) /\left(\mathrm{A} 490_{\text {control }}-\mathrm{A} 490_{\text {blank }}\right) \times 100 \%$.

Apoptosis assay. Apoptotic cells were detected using an Annexin V-FITC/PI kit (BioVision Inc., Milpitas, CA, USA). HepG2 and QGY7701 cells were seeded in 6-well plates at a density of $1 \times 10^{5}$ cells/well. According to the results of the MTT assay, the half maximal inhibitory concentration $\left(\mathrm{IC}_{50}\right)$ concentration of chrysin was acquired for each cell line using GraFit-Erithacus IC $_{50}$ software (Erithacus Software Ltd., Horley, UK). Lower $(20 \mu \mathrm{g} / \mathrm{ml})$ and higher dosages $(40 \mu \mathrm{g} / \mathrm{ml})$ were selected for the cell apoptosis assay. Cells were incubated in different concentrations of chrysin $(0,20$ and $40 \mu \mathrm{g} / \mathrm{ml}$ ) for $24 \mathrm{~h}$. The samples were then washed twice with cold D-Hank's buffer solution and resuspended in binding buffer $\left(1 \times 10^{6}\right.$ cells $\left./ \mathrm{ml}\right)$. Subsequently, $100 \mu \mathrm{l}$ cell supernatants were transferred to a tube with $5 \mu \mathrm{l}$ Annexin V-FITC (BD Biosciences, Franklin Lakes, NJ, USA) and $5 \mu \mathrm{l}$ PI (Beyotime Institute of Biotechnology). Following incubation for $15 \mathrm{~min}$ at room temperature in the dark, the apoptotic cells were detected using flow cytometry (FACS Canto II; BD Biosciences), and analyzed using Modfit and CellQuest 5.1 software (BD Biosciences). Cells located in the Q4 zone were deemed to be in the early apoptosis stage, whereas cells in the Q2 zone were in the late apoptosis stage.

Western blot analysis. Drug-induced cell apoptosis is due to mitochondrial dysfunction and apoptotic signaling pathway activation (13). p53, B-cell lymphoma ( $\mathrm{Bcl})-2$, Bcl-2-associated death promoter (Bad), Bcl-2-associated X (Bax), Bcl-2 homologous antagonist/killer (Bak), caspase-9 and caspase-3 are associated with apoptosis-induced mitochondrial damage (14); therefore the expression levels of these proteins were investigated. Cultured cells were collected and total protein was extracted using radioimmunoprecipitation assay lysis buffer [50 mmol/1 Tris (pH 7.4), $150 \mathrm{mmol} / \mathrm{l} \mathrm{NaCl}$, $1 \%$ Triton $\mathrm{X}-100,1 \%$ sodium deoxycholate, $0.1 \%$ sodium dodecyl sulfate, $1 \mathrm{mM}$ sodium orthovanadate, $1 \mathrm{mM}$ sodium fluoride, $1 \mathrm{mM}$ EDTA and $40 \mu \mathrm{g} . \mathrm{ml}$ leupeptin], containing $1 \mathrm{mM}$ phenylmethylsulfonyl fluoride (both Beyotime Institute of Biotechnology). After laying the extraction on ice for $30 \mathrm{~min}$, cell lysate was centrifuged for $12,000 \mathrm{x}$ g for $10 \mathrm{~min}$ at $4^{\circ} \mathrm{C}$ and the supernatants were collected. The total protein concentration in each supernatant sample was measured using a BCA protein assay kit (P0012; Beyotime Institute of Biotechnology).

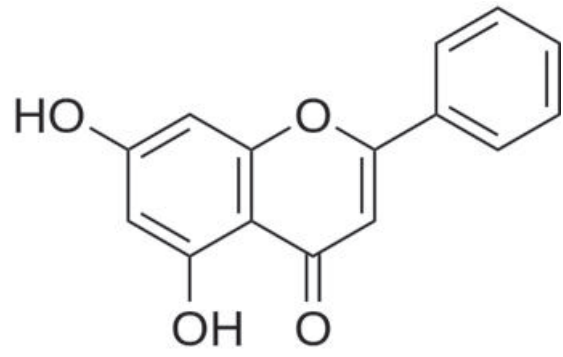

Figure 1. Molecular structure of chrysin.

Subsequently, proteins (20 $\mu \mathrm{g} /$ lane) were separated by $8 \%$ SDS-PAGE and transferred to a polyvinylidene difluoride membrane. Following blocking with $5 \%$ non-fat milk, the membrane was incubated with specific primary antibodies at a dilution of 1:1,000 for $2 \mathrm{~h}$ at room temperature. The following primary antibodies were used: p53 (2527), Bcl-2 (2870), Bax (5023), Bak (6947), Bad (9239), caspase-3 (9665), caspase-9 (9505) and GAPDH (2118; all Cell Signaling Technology, Beverly, CA, USA). The membrane was then washed three times in Tris-buffered saline-Tween 20 (TBST) for $5 \mathrm{~min}$, and incubated with a goat anti-rabbit horseradish peroxidase-labeled secondary antibody (E030120-01; EarthOx Life Sciences, Millbrae, CA, USA) at a dilution of 1:5,000 for $1 \mathrm{~h}$ at room temperature. Following three washes in TBST (10 min each), the membranes were exposed to an enhanced chemiluminescence buffer (EMD Millipore, Billerica, MA, USA) and measured on an Sally Sue western blot imaging system (ProteinSimple, San Jose, CA, USA). Gel images were then analyzed using ImageJ (National Institutes of Health, Bethesda, MA, USA) to calculate the gray value of each band.

Statistical analysis. Experiments were repeated $\geq 3$ times and all data were analyzed using Graphpad Prism 5.0 software. Between-group differences were analyzed using Student's t-test. Data are presented as the mean \pm standard deviation. $\mathrm{P}<0.05$ was considered to indicate a statistically significant difference $\left({ }^{*} \mathrm{P}<0.05 ;{ }^{* *} \mathrm{P}<0.01 ;{ }^{* * *} \mathrm{P}<0.001\right)$.

\section{Results}

Chrysin inhibits the viability of HCC cells. Following treatment of the QGY7701 and HepG2 cells with chrysin, the cells were found to slow growing, distorted, round in shape and detached from the bottom of the plate. Furthermore, the numbers of detached cells increased with increasing drug concentration (Figs. 2A and B). MTT assay was used to evaluate the viability of QGY7701 and HepG2 cells treated with chrysin. The present results revealed that, after $24 \mathrm{~h}$ of treatment, chrysin significantly inhibited cell viability in the HCC cell lines in a dose-dependent manner $(\mathrm{P}<0.001$; Figs. $2 \mathrm{C}$ and $\mathrm{D}) . \mathrm{IC}_{50}$ is an index for the evaluation of drug sensitivity. The $\mathrm{IC}_{50}$ values of chrysin in QGY7701 and HepG2 cells were measured using GraFit-Erithacus $\mathrm{IC}_{50}$ software and were found to be 18 and $25 \mu \mathrm{g} / \mathrm{ml}$, respectively.

Chrysin promotes HCC cell apoptosis. The apoptosis of the QGY7701 and HepG2 cells was detected using 


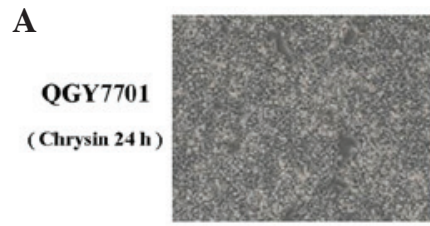

Control

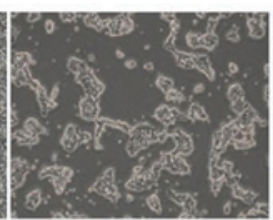

$10 \mu \mathrm{g} / \mathrm{ml}$

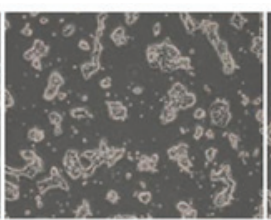

$20 \mu \mathrm{g} / \mathrm{ml}$

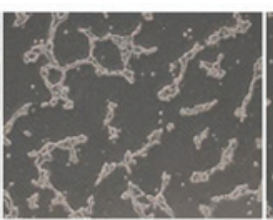

$40 \mu \mathrm{g} / \mathrm{ml}$

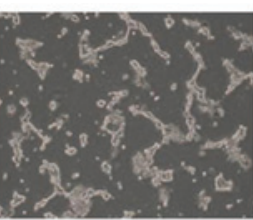

$60 \mu \mathrm{g} / \mathrm{ml}$

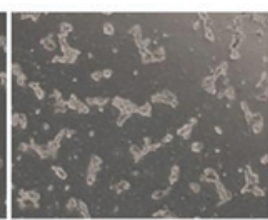

$80 \mu \mathrm{g} / \mathrm{ml}$

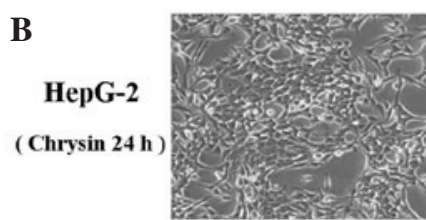

Control

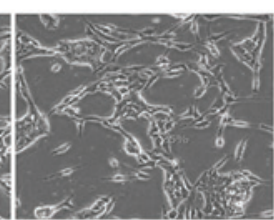

$10 \mu \mathrm{g} / \mathrm{ml}$

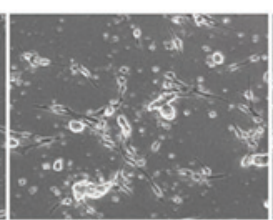

$20 \mu \mathrm{g} / \mathrm{ml}$

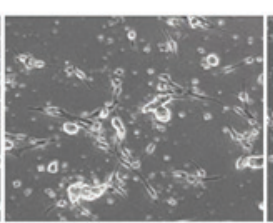

$40 \mu \mathrm{g} / \mathrm{m}$

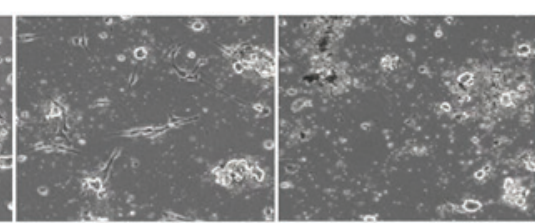

$60 \mu \mathrm{g} / \mathrm{ml}$

$80 \mu \mathrm{g} / \mathrm{ml}$
C

QGY7701

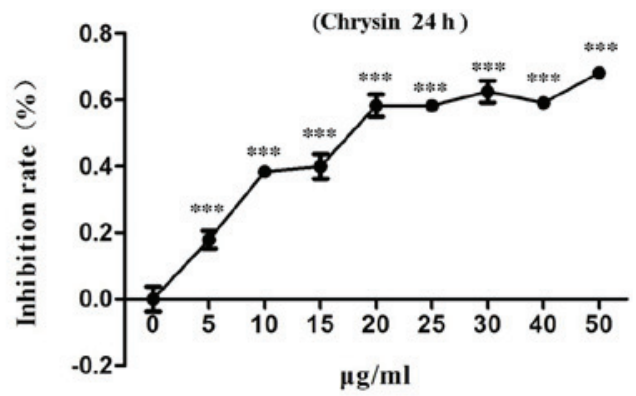

D

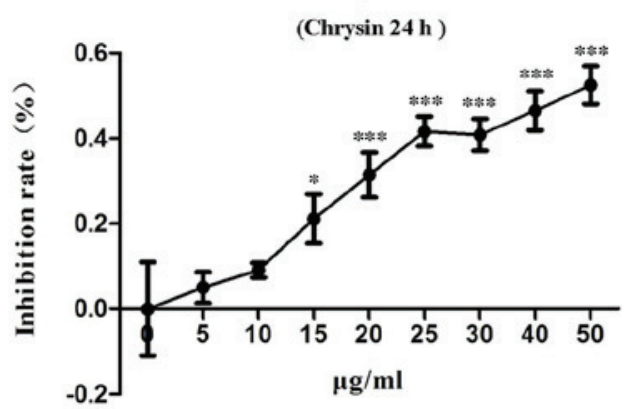

Figure 2. Various concentrations of 24-h chrysin treatment inhibited HepG2 and QGY7701 cell viability. Microscopic analysis of (A) QGY7701 and (B) HepG2 cells (magnification, x100). Quantification of MTT assay data for (C) QGY7701 and (D) HepG2 cells. Data are presented as the mean \pm standard deviation $(\mathrm{n}=5) .{ }^{*} \mathrm{P}<0.05$ and ${ }^{* * *} \mathrm{P}<0.001$ vs. $0 \mu \mathrm{g} / \mathrm{ml}$ chrysin.

Annexin V/PI double staining and flow cytometric analysis. The results indicated that chrysin induced HCC cell apoptosis. Chrysin induced-apoptosis in HepG2 and QGY7701 cells was found to significantly increase in a concentration-dependent manner (P<0.001; Fig. 3). QGY7701 cells were found to be more sensitive to chrysin treatment, with higher levels of apoptosis observed compared with the HepG2 cells.

p53/Bcl-2/caspase-9 signaling pathway activation following treatment with chrysin in HCC cells. HCC cells were treated with various concentrations of chrysin for $24 \mathrm{~h}$. Apoptosis protein expression levels of cleaved caspase- 3 and caspase- 9 were found to significantly increase in a concentration-dependent manner following chrysin treatment in the QGY7701 and HepG2 cell lines ( $\mathrm{P}<0.001$; Fig. 4). These results indicated that the caspase-9/caspase-3-associated apoptosis pathway was activated. In addition, the possible activation of the p53/Bcl-2 signaling pathway was also investigated based on the protein expression levels of p53, Bcl-2, Bax, Bad and Bak. The results demonstrated that this intrinsic apoptosis pathway was also activated following chrysin treatment in the two HCC cell lines ( $\mathrm{P}<0.001$; Fig. 4).

\section{Discussion}

HCC is a highly malignant tumor that affects individuals worldwide. Efficacious chemotherapeutic is critical for the eradication of tumors that cannot be completely removed by surgery. Although there are several therapeutic agents for the management of $\mathrm{HCC}$, drug resistance and adverse effects remain pivotal issues (3). Natural products are a large source of novel therapeutic agents and natural products have been widely investigated as anti-cancer drugs, however the exact mechanism of their anti-cancer action requires further elucidation. In the present study, chrysin was demonstrated to significantly inhibit the viability of two HCC cell lines, suggesting that chrysin may comprise a novel candidate agent for the treatment of HCC.

Cell apoptosis is a complicated biological process that is associated with complex signaling pathway responses. The activation of cysteine proteases, in particular caspases, is a key intracellular regulator of cell apoptosis $(15,16)$. Caspase-3 is an important mediator of apoptosis (17) that is activated by a variety of activators classified into two main signaling pathways: The death receptor-mediated pathway, involving caspase- 8 and caspase-10, and the mitochondria-mediated pathway, involving caspase-9 $(18,19)$. Caspase-3 is an executioner caspase that is activated by death ligands and mitochondrial dysfunction-induced cell apoptosis (20). In the present study, chrysin treatment was not found to have a significant effect on the expression of caspase-8, but promoted the accumulation of cleaved caspase- 9 , suggesting that chrysin selectively induces apoptosis in HCC cells via the mitochondria-mediated apoptosis pathway. Due to the role of caspase-3 as an executioner of cell apoptosis, caspase-3 expression levels were also detected to confirm cell apoptosis. The results demonstrated that caspase- 3 was cleaved significantly, indicating that the cells were undergoing apoptosis. 
A

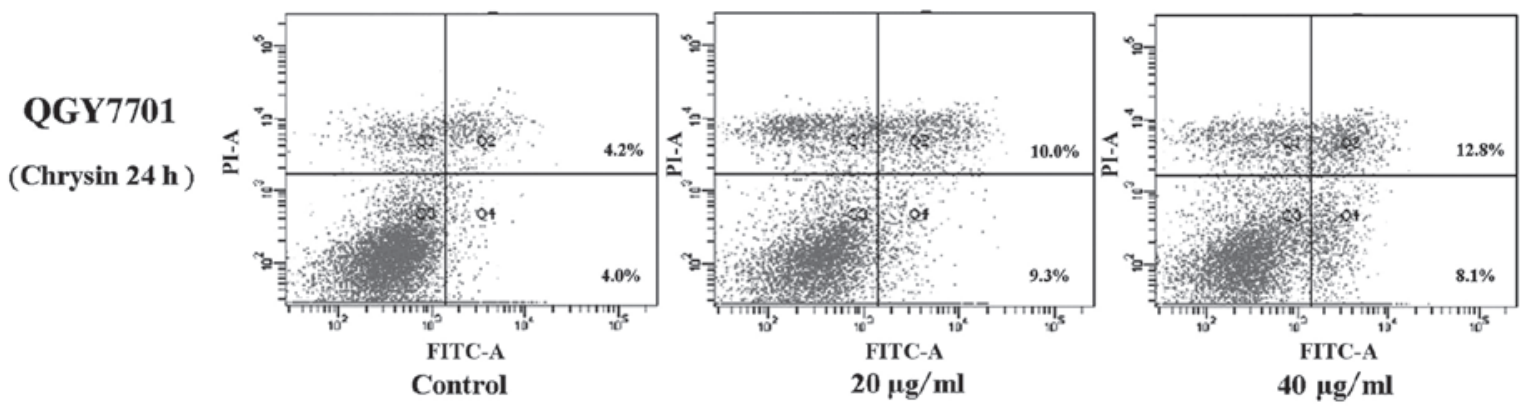

B
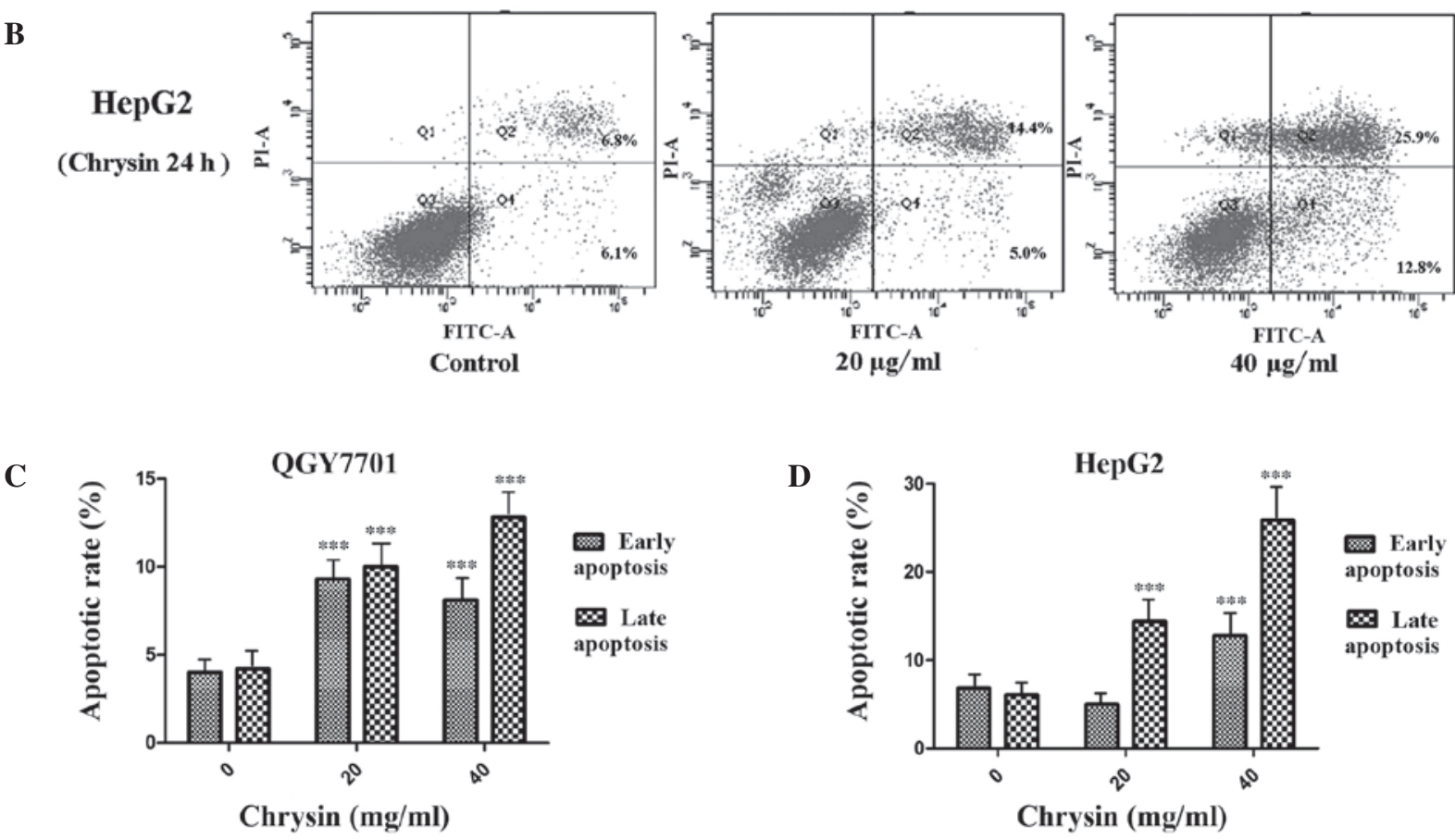

Figure 3. Chrysin promotes cell apoptosis in HepG2 and QGY7701 cells. Apoptotic rate in (A) HepG2 and (B) QGY7701 cells following treatment with various concentrations of chrysin for $24 \mathrm{~h}$. Apoptotic cells were detected using flow cytometry. Quantification of the flow cytometry data for (C) QGY7701 and (D) HepG2 cells identified the rates of early and late chrysin-induced apoptosis. Data are presented as the mean \pm standard deviation $(\mathrm{n}=3)$. ${ }^{* * *} \mathrm{P}<0.001$ vs. $0 \mu \mathrm{g} / \mathrm{ml}$ chrysin.

The tumor suppressor protein, p53, is a positive regulator of the Bax, Bad and Bak proapoptotic proteins to prevent Bcl-2 capture. Free Bax, Bad and Bak subsequently bind to the mitochondrial membrane to induce mitochondrial damage and cell apoptosis (21-23). Previous studies have demonstrated that p53 promotes the transcription of $\mathrm{Bax}$ and $\mathrm{Bak}$, which regulate the release of cytochrome $c$ from the mitochondria, and result in cell apoptosis by activating the cleaving of caspase- 3 and caspase-9 (22,24). In the present study, p53, Bax, Bad and Bak were found to be significantly upregulated, whereas Bcl-2 was found to be downregulated in the HepG2 and QGY7701 cells following chrysin treatment. These results suggested that chrysin upregulates p53 and activates its downstream target gene, which induces mitochondrial dysfunction by releasing cytochrome $c$ and inducing the apoptosis of cancer cells. Cell apoptosis is a process of programmed cell death which includes early membrane extroversion in the early stage and cell membrane disruption and cell death during late apoptosis. In the present study, it was demonstrated that the early and late stages of apoptosis were increased in QGY7701 cells; whereas only late apoptosis was increased in HepG2 cells. Notably, significantly more HepG2 cells were killed, as compared with QGY7701 cells, which suggests that chrysin may have a stronger effect on HepG2 cells by promptly inducing late cell apoptosis. These results demonstrated that the anti-cancer effect of chrysin anticancer effect is associated with the genetic background of the cancer cells rather than a general cytotoxic effect.

In conclusion, the results of the present study suggested that chrysin effectively inhibits cell viability and induces cell apoptosis in HCC cells. It was confirmed that chrysin promoted $\mathrm{HCC}$ cell apoptosis via the activation of the $\mathrm{p} 53 / \mathrm{Bcl} 2 / \mathrm{caspase}-9$ apoptotic signaling pathway. Based on the aforementioned findings, the present study suggests that chrysin may be a candidate agent for the treatment of human HCC.

\section{Acknowledgements}

The present study was supported by grants from the Special Funds from Education Department of Guangdong Province (grant no. JB1212), the Chinese NSFC grants (grant no. 31370824), the Yangfan Plan of Talents Recruitment Grant, Guangdong, China (grant nos. YueRenCaiBan[2014]1 and YueRenCaiBan[2016]1), the University Talents Recruitment 
A
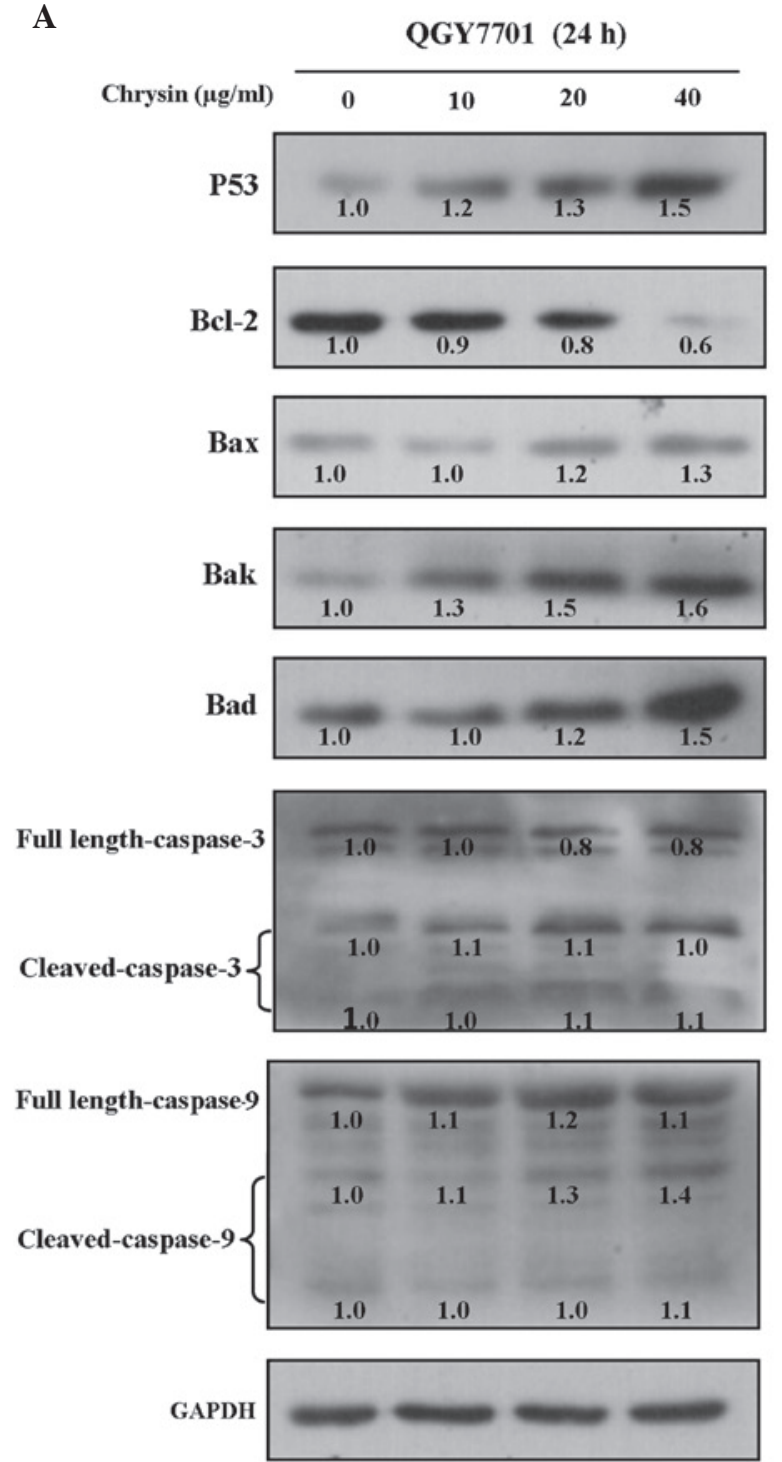

B
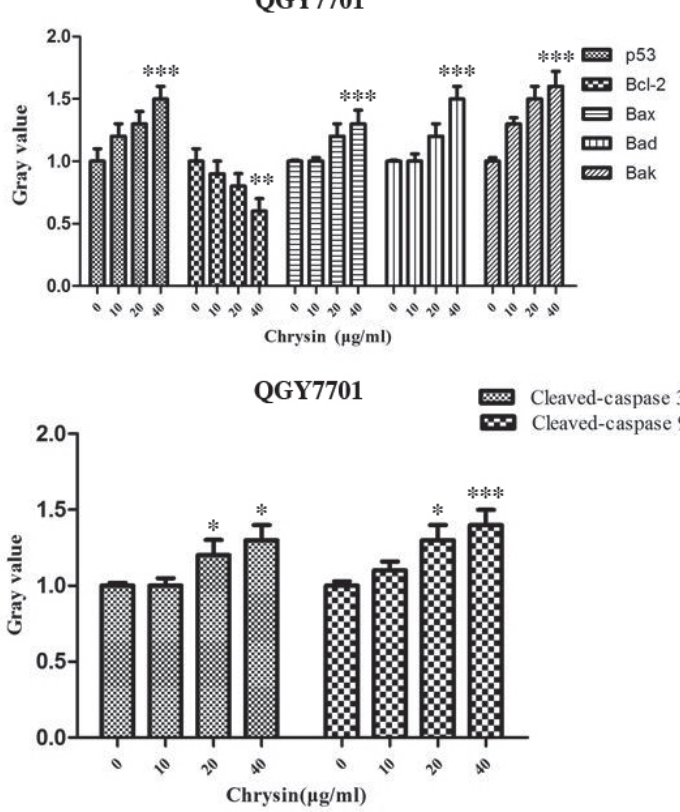

HepG2 (24 h)
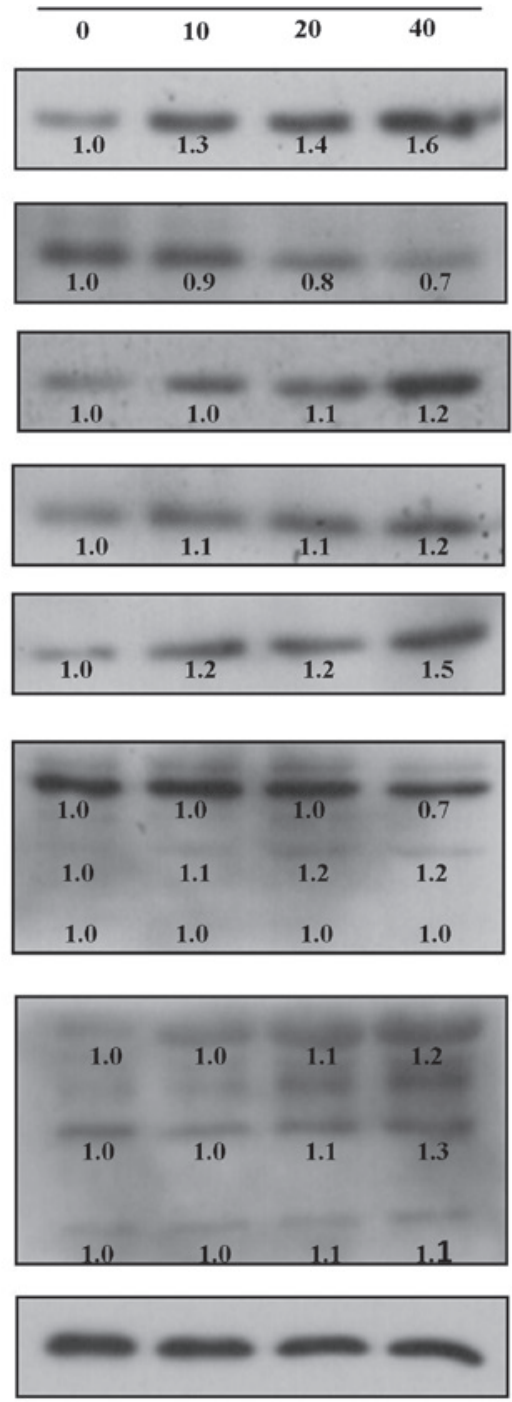

Hep G2
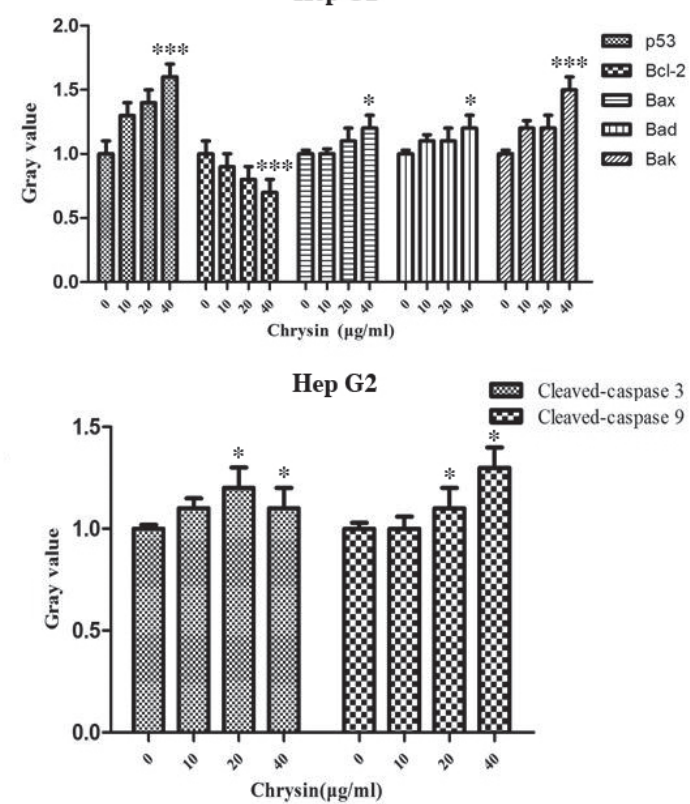

Figure 4. Chrysin regulates the p53/Bcl-2/caspase-9 signaling pathway. Chrysin regulates the content of apoptotic-related proteins in HepG2 and QGY7701 cells following various concentrations of chrysin treatment for $24 \mathrm{~h}$. (A) Western blotting was performed in order to analyze the protein content of p53, Bcl-2, Bax, Bak, Bad, caspases-3 and -9 , and cleaved-caspases-3 and -9 (B) and this data was subsequently quantified. ${ }^{*} \mathrm{P}<0.05$, ${ }^{* *} \mathrm{P}<0.01$ and ${ }^{* * * *} \mathrm{P}<0.001$ vs. $0 \mu \mathrm{g} / \mathrm{ml}$ chrysin. Bcl-2, B-cell lymphoma-2; Bax, Bcl-2-associated X; Bad, Bcl-2-associated death promoter; Bak, Bcl-2 homologous antagonist/killer. 
Grant of Guangdong, China (grant no. YueCaiJiao[2012]328), The Excellent Postgraduate Essay Development Project of Guangdong Medical College (grant no. 2014-18) and the Key Laboratory of Zhanjiang project (grant no. 2013A402-4).

\section{References}

1. Jemal A, Bray F, Center MM, Ferlay J, Ward E and Forman D: Global cancer statistics. CA Cancer J Clin 61: 69-90, 2011.

2. Forner A, Llovet JM and Bruix $\mathbf{J}$ : Hepatocellular carcinoma. Lancet 379: 1245-1255, 2012.

3. Au JS and Frenette CT: Management of hepatocellular carcinoma: Current status and future directions. Gut Liver 9 437-448, 2015

4. Fitzmorris P, Shoreibah M, Anand BS and Singal AK: Management of hepatocellular carcinoma. J Cancer Res Clin Oncol 141: 861-876, 2015.

5. Manfredi JJ and Horwitz SB: Taxol: An antimitotic agent with a new mechanism of action. Pharmacol Ther 25: 83-125, 1984.

6. Pichichero E, Cicconi R, Mattei M, Muzi MG and Canini A: Acacia honey and chrysin reduce proliferation of melanoma cells through alterations in cell cycle progression. Int J Oncol 37: 973-981, 2010.

7. Barbarić $M$, Mišković $K$, Bojić $M$, Lončar MB Smolčić-Bubalo A, Debeljak Z and Medić-Šarić M: Chemical composition of the ethanolic propolis extracts and its effect on HeLa cells. J Ethnopharmacol 135: 772-778, 2011.

8. Khan R, Khan AQ, Qamar W, Lateef A, Tahir M, Rehman MU, Ali F and Sultana S: Chrysin protects against cisplatin-induced colon toxicity via amelioration of oxidative stress and apoptosis: Probable role of p38MAPK and p53. Toxicol Appl Pharmacol 258: 315-329, 2012.

9. Cherkaoui-Tangi K, Lachkar M, Wibo M, Morel N, Gilani AH and Lyoussi B: Pharmacological studies on hypotensive, diuretic and vasodilator activities of chrysin glucoside from Calycotome villosa in rats. Phytother Res 22: 356-361, 2008.

10. Song MY, Jeong GS, Kwon KB, Ka SO, Jang HY, Park JW, Kim YC and Park BH: Sulfuretin protects against cytokine-induced beta-cell damage and prevents streptozotocin-induced diabetes. Exp Mol Med 42: 628-638, 2010.

11. Tahir M and Sultana S: Chrysin modulates ethanol metabolism in Wistar rats: A promising role against organ toxicities. Alcoho Alcohol 46: 383-392, 2011.
12. Yang F, Jin H, Pi J, Jiang JH, Liu L, Bai HH, Yang PH and Cai JY: Anti-tumor activity evaluation of novel chrysin-organogermanium (IV) complex in MCF-7 cell. Bioorg Med Chem Lett 23: 5544-5551, 2013.

13. Wen S, Zhu D and Huang P: Targeting cancer cell mitochondria as a therapeutic approach. Future Med Chem 5: 53-67, 2013.

14. Brunelle JK and Letai A: Control of mitochondrial apoptosis by the Bcl-2 family. J Cell Sci 122: 437-441, 2009.

15. Mu R, Lu N, Wang J, Yin Y, Ding Y, Zhang X, Gui H, Sun Q et al: An oxidative analogue of gambogic acid-induced apoptosis of human hepatocellular carcinoma cell line HepG2 is involved in its anticancer activity in vitro. Eur J Cancer Prev 19: 61-67, 2010.

16. Alenzi FQ, Alenazi BQ, Al-Anazy FH, Mubaraki AM, Salem ML, Al-Jabri AA, Lotfy M, Bamaga MS, Alrabia MW and Wyse RK: The role of caspase activation and mitochondrial depolarisation in cultured human apoptotic eosinophils. Saudi J Biol Sci 17: 29-36, 2010.

17. Wolf BB, Schuler M, Echeverri F and Green DR: Caspase-3 is the primary activator of apoptotic DNA fragmentation via DNA fragmentation factor-45/inhibitor of caspase-activated DNase inactivation. J Biol Chem 274: 30651-30656, 1999.

18. Fan TJ, Han LH, Cong RS and Liang J: Caspase family proteases and apoptosis. Acta Biochim Biophys Sin (Shanghai) 37: 719-727, 2005.

19. Ling Y, Lu N, Gao Y, Chen Y, Wang S, Yang Y and Guo Q: Endostar induces apoptotic effects in HUVECs through activation of caspase-3 and decrease of Bcl-2. Anticancer Res 29: 411-417, 2009.

20. Slee, EA, Adrain C and Martin SJ: Executioner caspase-3, -6, and -7 perform distinct, non-redundant roles during the demolition phase of apoptosis. J Biol Chem 276: 7320-7326, 2001.

21. Cheng EH, Wei MC, Weiler S, Flavell RA, Mak TW, Lindsten T and Korsmeyer SJ: Bcl-2, Bcl-X(L) sequester BH3 domain-only molecules preventing BAX and BAK-mediated mitochondrial apoptosis. Mol Cell 8: 705-711, 2001.

22. Degenhardt K, Chen G, Lindsten T and White E: BAX and BAK mediate p53 independent suppression of tumorigenesis. Cancer Cell 2: 193-203, 2002.

23. Liu J, Shu Y, Zhang Q, Liu B, Xia J, Qiu M, Miao H, Li M and Zhu R: Dihydromyricetin induces apoptosis and inhibits proliferation in hepatocellular carcinoma cells. Oncol Lett 8: 1645-1651, 2014.

24. Henry H, Thomas A, Shen Y and White E: Regulation of the mitochondrial checkpoint in p53 mediated apoptosis confers resistance to cell death. Oncogene 21: 748-760, 2002. 